\title{
Acute and residual concentration- dependent toxicities of some selected insecticides to adult Bactrocera invadens Drew, Tsuruta and White (Diptera: Tephritidae)
}

\author{
G. Abdullahi ${ }^{1 *}$ (D, D. Obeng-Ofori ${ }^{2}$, K. Afreh-Nuamah ${ }^{3}$ and M. K. Billah ${ }^{4}$
}

\begin{abstract}
Background: The high yield loss reported from the infestations of fruits by Bactrocera invadens Drew, Tsuruta and White in West Africa can impact negatively on the growth of horticulture in the region. Similarly, the shortage of insecticides specifically registered for the control of this pest in Ghana makes decision by farmers on which insecticide to use against this pest uncertain and risky.

Results: The result for the acute lethal toxicity shows that the lethal concentration (LC) values of the tested insecticides are 0.59 (diazinon (Diazol)), 0.81 (chlorpyrifos (Pyrinex)), 1.21 (cypermethrin+dimethoate (Cydim super)), and 3.12 (deltamethrin (Deltapaz)) $\mathrm{ml} \mathrm{L}^{-1}$ of water. The result for the residual toxicities of three concentrations for each of the tested insecticides shows that the lethal times $L T\left(L T_{50}\right.$ and $\left.{ }_{90}\right)$ for the adult $B$. invadens differed significantly for all the ages of the residues. Some insecticides exhibited low lethal time even on panels that are up to 6 days old after treatment.

Conclusion: We concluded that the acute lethal toxicity of the insecticides from most-to-least toxic are diazinon $($ Diazol) $>$ chlorpyrifos (Pyrinex) > cypermethrin + dimethoate (Cydim super) $>$ deltamethrin (Deltapaz). The residual toxicity of the label rates of all the insecticides are equal to those of the higher doses but better than those of the least doses. The implication of these findings for the management of $B$. invadens has been discussed.
\end{abstract}

Keywords: Lethal concentration, Management, Rearing, Bioassay, Tephritid fruit fly

\section{Introduction}

Tephritid fruit flies are pest of major significance in most fruit and fruity vegetable crops (Vayssières et al., 2011; Vayssières, Sanogo, \& Noussourou, 2007; White \& Elson-Harris, 1992; Wih \& Billah, 2012). They have been reported to cause colossal economic destruction and losses in important tropical crops like citrus, mangoes, papaya, and guava (Badii, Billah, Afreh-Nuamah, \& Obeng-Ofori, 2015; Ekesi \& Billah, 2006; Umeh, Garcia, \& De Meyer, 2008; Vayssières et al., 2007, 2011). Several

\footnotetext{
* Correspondence: gatsaranyi@yahoo.com

${ }^{1}$ Department of Crop Protection, Modibbo Adama University of Technology, Yola, Nigeria

Full list of author information is available at the end of the article
}

species of fruit flies including Bactrocera invadens Drew, Tsuruta and White, Ceratitis capitata (Wiedemann), B. dorsalis (Hendel), and B. curcubitacea (Coquillett) among others have been implicated globally in causing the afore mentioned damage leading to vast economic loss (Badii et al., 2015; Ekesi, Nderitu, \& Rwomushana, 2006; Rwomushana, Ekesi, Gordon, \& Ogal, 2008).

In west Africa, B. invadens have been reported to cause damage in the range of $17-73 \%$ on total fruits yield in Mango (Vayssières et al., 2007, 2011). This damage regime will have monumental effects on the sustainable productions of fruits (especially mango) in the region and other similar ecologies known to be within the geographical range of this pest (Copeland, 2006). 
Sequel to this, exploring effective and appropriate management strategies to protect plantation from tephritid fruit flies pressure has become a matter of great urgency (Vayssières et al., 2011).

Despite the existence of other control methods against B. invadens, the use of synthetic insecticides still plays a central role in adult population suppressions programmes (Bateman, 1982; Vayssières et al., 2011), as the eggs are normally deposited inside the fruit and hatch therein into a larvae that feeds and develop to the last instars within the fruits, creating galleries that permits the opportunist micro-organism invasion with consequent decay of tissues around such galleries (Ekesi \& Billah, 2006). Likewise, given the array of insecticidal products used by farmers for the control of fruit flies in Ghana, there are limited products that have been specifically registered for this purpose (Badii, Billah, AfrehNuamah, \& Obeng-Ofori, 2012; EPA, 2008). Also, information on both the acute and residual toxicities of these products against especially $B$. invadens are lacking in the literature. Hence, the choice of the mango farmers of any of these insecticides depends on recommendations of such insecticides for control of other pests on mango and other fruits, a practice which does not work well for most pest problems (Raga \& Sato, 2006; Vayssières et al., 2011). This study was therefore carried out with the sole aim of generating information on the acute and dosedependent residual toxicities of some selected insecticides commonly used by mango farmers in Ghana against $B$. invadens.

\section{Materials and methods}

Rearing of the Adult $B$. invadens used

Adult fruit flies used in this experiment were reared out of infested fruits collected from the field and processed as described by Copeland (2006) and Rwomushana et al. (2008). Fruits were placed on large plastic racks with trays of pre-sterilized moistened sand under the container to collect exiting larvae (Fig. 1a) or incubated in plastic bowls lined with sand (Fig. 1b). The sand was heat-sterilized at $100{ }^{\circ} \mathrm{C}$ for $12 \mathrm{~h}$. Fruits were dissected after 2 weeks of incubation to remove any remaining larvae that may prefer to remain inside the rotting fruit if the outside environment is not conducive (Billah, personal communication). After 3 days, the sand was sieved to recollect the puparia, which were placed in petri dishes lined with moist filter paper. Daily check for emerged insect was done, and the emerged insects were transferred into holding cages (Fig. 1c). Adult insects were allowed to stay for 3-4 days to achieve full adult characteristics to facilitate proper identification. They were provided with water-soaked cotton wool and fed on a diet containing pure baker's yeast and sugar (1 yeast to 3 sugar or natural honey, v/v combination).

Adult fruit flies were identified using literature and keys of Billah and Mansell (2006); De Meyer (1998, 2000); Drew, Tsuruta, and White (2005) and White and Elson-Harris (1992). Where there was doubt, flies were sent to Dr. M. K. Billah (Department Animal biology and conservation studies, University of Ghana) for confirmation.

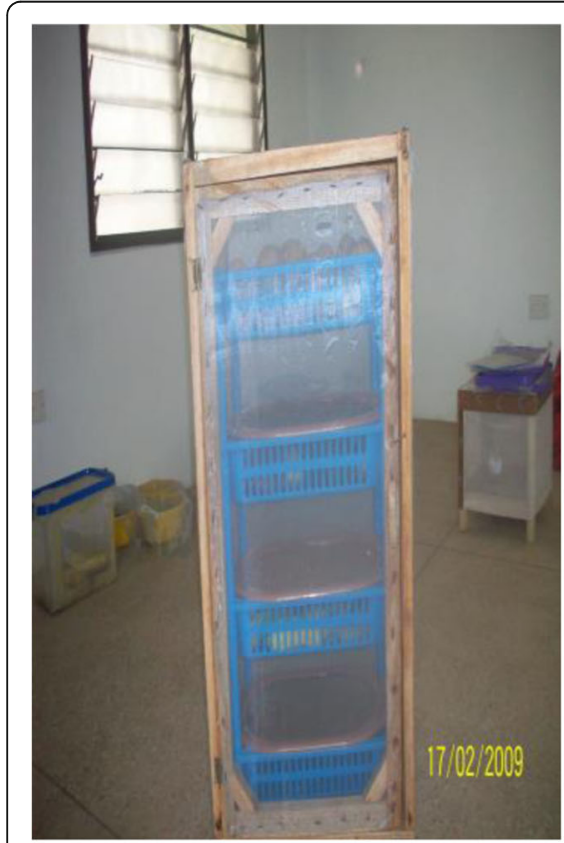

a

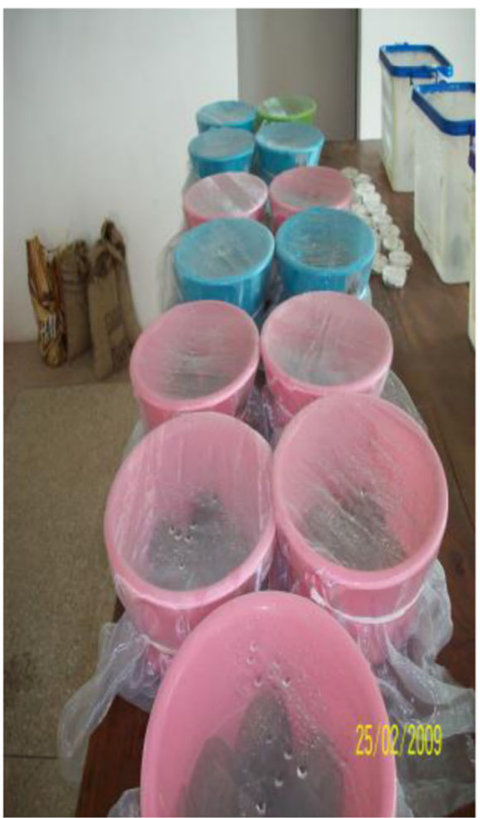

b

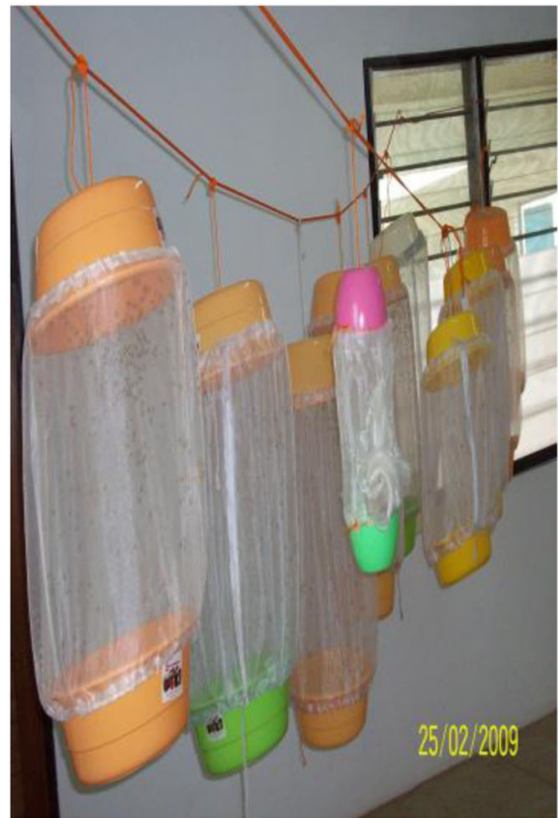

C

Fig. 1 Incubation of mango/fruits on (a) plastic racks and in (b) plastic bowls for rearing flies, Adult fruit flies holding cages (c) 


\section{Insecticides products used}

Four commercial insecticidal products: cypermethrin+dimethoate (Cydim super ${ }^{\mathrm{Tm}}$ ), chlorpyrifos (Pyrinex $48 \mathrm{EC}^{\mathrm{Tm}}$ ), diazinon (Diazol $50 \mathrm{EW}^{\mathrm{m}}$ ), and deltamethrin $\left(\right.$ Deltapaz ${ }^{\mathrm{Tm}}$ ) were evaluated during the study. Cydim super is an emulsifiable concentrate containing $36 \mathrm{~g}$ cypermethrin and $400 \mathrm{~g}$ dimethoate per liter. It is manufactured by Iprochem Company limited (Shenzen, China) and distributed in Ghana by Agrimat Ltd (Agrimat House, Madina). Pyrinex $48 \mathrm{EC}^{\mathrm{mm}}$ contains chlorpyrifos $480 \mathrm{~g} / \mathrm{L}$. It is manufactured by Makhteshim Chemical Works Ltd (Beer Sheva, Israel) and distributed in Ghana by Dizengoff (Gh) Ltd. Diazol 50 EW contains diazinon 500 g/L. It is manufactured by Makhteshim chemical works Ltd (Beer Sheva, Israel) and distributed in Ghana by Dizengoff (Gh) Ltd. Deltamethrin (Deltapaz) contains deltamethrin $12.5 \mathrm{~g} / \mathrm{L}$, manufactured by Makhteshim chemical works Ltd, Beer sheva, Israel, and distributed in Ghana by Dizengoff (Ghana) Ltd.

\section{Determination of acute toxicities of the insecticidal product}

To determine the lethal concentration (LC) values of the products, the commercial grade of each product was diluted as follows: cypermethrin + dimethoate, 0.90, 1.60, 2.30, and $3.00 \mathrm{ml} \mathrm{L}^{-1}$; chlorpyrifos, $0.80,0.90,1.00$, and $1.10 \mathrm{ml} \mathrm{L}^{-1}$; diazol, 1.20, 1.80, 2.50, and $3.20 \mathrm{ml} \mathrm{L}^{-1}$, and detamethrin, 2.00, 2.60, 3.40, and $4.00 \mathrm{ml} \mathrm{L}^{-1}$. The hard cardboard panels were dipped into the solution of the respective concentration for each product and allowed to dry for $10 \mathrm{~min}$ under the shade in the lab. The bioassays were conducted in 1-L transparent bottles fitted with yellow caps, from which treated cardboard panels $(4 \times 4 \mathrm{~cm})$ were hanged (Fig. 2). A hundred and fifty
(150) holes of $1.5 \mathrm{~mm}$ diameter were made on the sides of the bottles for ventilation during the bioassay (Cheng, Cho, \& $\mathrm{Li}, 2009$ ). A hole of $1.5 \mathrm{~mm}$ in diameter was made at the center of the bottles' yellow cap to hang the treated panels with the aid of a string attached to the panels (Fig. 2). Ten adult B. invadens of mixed sexes in three replicates for each product were added to the treated panels in transparent bottles. Observations for mortalities were done every $2 \mathrm{~min}$ for $30 \mathrm{~min}$. Data on mortalities were recorded at each interval and used to determine the $\mathrm{LC}$ values.

\section{Insecticide concentration-dependent efficacy bioassay}

Insecticide concentration-dependent efficacy was determined by calculating the lethal time $\left(\mathrm{LT}_{50}\right.$ and $\left.\mathrm{LT}{ }_{90}\right)$ values for the field strain of adult $B$. invadens for each candidate insecticide. All bioassays were conducted in the Research Laboratory at the African Regional Postgraduate Programme in Insect Science (ARPPIS) building, University of Ghana, Legon, under $28 \pm 2{ }^{\circ} \mathrm{C}, \mathrm{RH}$ $68-81 \%$ and photoperiod of $12: 12 \mathrm{D}$ to L hours. Bioassays were conducted in a 1-L transparent bottle as described in Section 2.3 above with modification on the mode of treatment of hard cardboard panels. Here, the hardboard panels were dipped into a solution of the test insecticides at three different concentrations for each insecticidal product for $2 \mathrm{~min}$. The rates used to get the respective solutions are $10 \mathrm{ml}$ below the manufacturers' recommended rate (lowest concentration), the manufacturers' recommended field label rate (median concentration), and $10 \mathrm{ml}$ above the manufacturers' recommended rate (highest concentration) (Moore and Miller 2006). Thus, 1.6, 2.3, and $3.0 \mathrm{ml}$ of cypermethrin+dimethoate (Cydim super) per liter of water chlorpyrifos (Pyrinex)

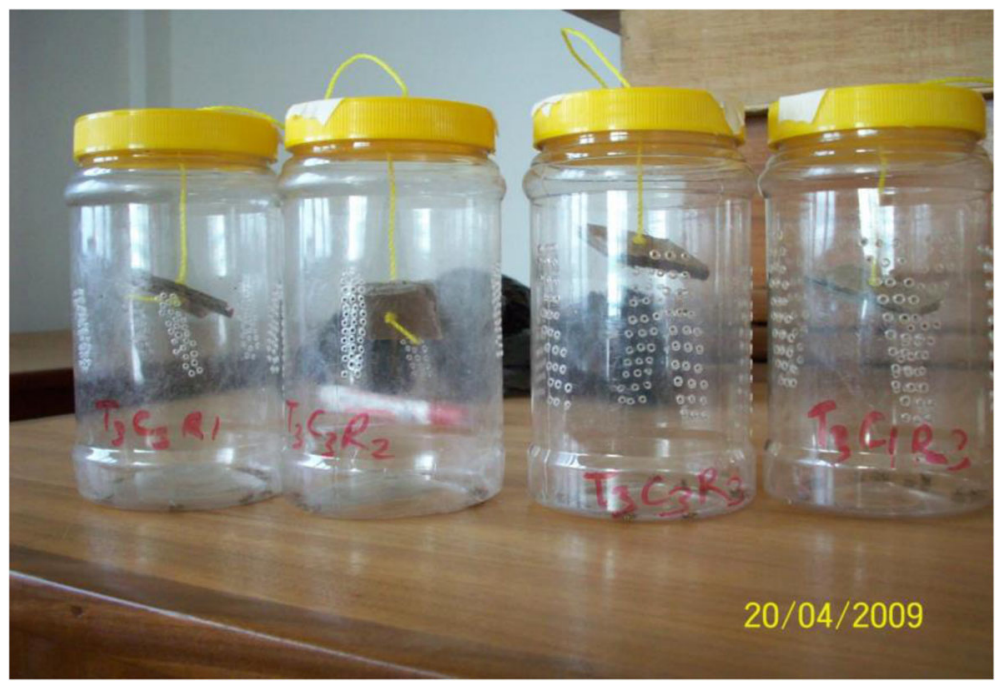

Fig. 2 Insecticides efficacy bioassay system 
$48 \mathrm{EC}$ were used at the rates of $0.9,1.0$, and $1.10 \mathrm{ml} \mathrm{L}^{-1}$ of water, diazinon (Diazol) $50 \mathrm{EW}$ was used at the rates of $1.8,2.5$, and $3.2 \mathrm{ml} \mathrm{L}^{-1}$ of water, and deltamethrin (Deltapaz) was used at the rate of $2.6,3.4$, and $4.0 \mathrm{ml}$ $\mathrm{L}^{-1}$ of water for the concentration-dependent and residual toxicity bioassay. Prior to introduction of the insects, the treated panels were allowed to dry under laboratory condition for $20 \mathrm{~min}$. Then, ten adult B.invadens of mixed sexes (five males and five females) aged 4-12 days were collected from the rearing cages using a $1.5 \mathrm{~cm}$ diameter vial and introduced into the bioassay bottles containing the treated panels. The lids of the bottles were replaced and keep in an upright position (Fig. 2).

Observations for mortalities were made at least once every $5 \mathrm{~min}$. Adult flies that were knocked down and could not move any appendages for $30 \mathrm{~s}$ after responding to the insecticides were considered dead. The respective mortalities and times taken (lethal time (LT)) for 50 and $90 \%$ of the introduced flies to die were recorded and used to determine $\mathrm{LT}_{50}$ and $\mathrm{LT}_{90}$, for a treatment and concentration level using probit analysis. Three experiments were conducted based on the age (in days) of the treated panels to test the residual toxicities of the insecticides for each of concentration. Thus, (1) freshly treated panels (20 min after dipping), (2) 3-dayold treated panels (72 hours after dipping), and (3) 6day-old treated panels (144 h after dipping) (Urbaneja et al. 2009). In each experiment, all treatments were replicated three (3) times. A similar panel treated with only water before exposure to insects was used as a control for the different doses of the four insecticides.

\section{Statistical analysis}

Insecticide acute toxicities were determined within 30 min and expressed in LC values, and their 95\% confidence limits and slope of regression lines determined by probit analysis (EPA probit analysis program, version 1.5). Data on lethal times were subjected to one-way ANOVA in GENSTAT statistical packages (GenStat Release 9.2 (PC/Windows) Genstat, 2007, Lawes Agricultural Trust (Rothamsted Experimental Station) 9th Edition). Means were separated using the least significant difference (LSD; $P<0.05$ ). Prior to analysis, mortalities exceeding $5 \%$ in the controls were corrected for natural mortality using Abbotts' formula (Abbott, 1925).

\section{Results}

Acute toxicities of the selected insecticidal products

The acute toxicities of the insecticidal products tested are shown in Table 1 . The $\mathrm{LC}_{50}$ values of all tested products are low, ranging from 0.59 (diazinon (Diazol)) to 3.10 (deltamethrin (Deltapaz)) $\mathrm{ml} \mathrm{L}^{-1}$. The toxicity ranges from most-to-least toxic are diazinon (Diazol) > chlorpyrifos (Pyrinex) > cypermethrin+dimethoate (Cydim super) > deltamethrin (Deltapaz), respectively. The $\mathrm{LC}_{90}$ values of the tested products ranged from 1.03 chlorpyrifos (Pyrinex) to 5.23 deltamethrin (Deltapaz) $\mathrm{ml}$ $\mathrm{L}^{-1}$; hence, the toxicity ranges from most-to-least toxic are chlorpyrifos (Pyrinex) $>$ diazinon (Diazol) $>$ cypermethrin+dimethoate (Cydim super) and deltamethrin (Deltapaz). Similarly, the 95\% fiducial limits (FL) (0.55$0.89 \mathrm{ml} \mathrm{L}^{-1}$ ) for chlorpyrifos (Pyrinex) and cypermethrin+dimethoate (Cydim super) ( $\mathrm{LC}_{50} 0.4-1.68 \mathrm{ml} \mathrm{L}^{-1}$ ) for the $\mathrm{LC}_{50}$ overlapped. Also, the $95 \% \mathrm{FL}$ for deltamethrin (Deltapaz) (4.01-18.49 $\left.\mathrm{ml} \mathrm{L}^{-1}\right)$ and cypermethrin+dimethoate (Cydim super) (2.11-15.56 $\mathrm{ml} \mathrm{L}^{-1}$ ) overlapped at their $\mathrm{LC}_{90}$ values (Table 1 ).

\section{Concentration-dependent lethal times residual toxicities of the insecticidal products \\ Cypermethrin+dimethoate (Cydim super)}

The results of the concentration-dependent toxicity level comparisons for cypermethrin+dimethoate (Cydim super) across the residue ages are shown in Table 2. As expected, freshly treated panels with $3.0 \mathrm{ml} \mathrm{L}^{-1}$ cypermethrin+dimethoate (Cydim super) was more toxic to the flies and gave the least mortality times $\left(\mathrm{LT}_{50}=29.67\right.$ \pm 13.68 and $\left.\mathrm{LT}_{90}=73.67 \pm 41.67 \mathrm{~min}\right)$. However, the differences between the mean $\mathrm{LT}_{50}$ values for all concentration levels were not significant except for the control that was highly significantly $(P<0.001)$ higher than all. However, the difference between $\mathrm{LT}_{90}$ values of the least and the highest concentration $\left(1.6\right.$ and $\left.3.0 \mathrm{ml} \mathrm{L}^{-1}\right)$ were highly significant $(P<0.001)\left(\mathrm{LT}_{90}=128.00 \pm\right.$ 20.81 and $73.67 \pm 41.67 \mathrm{~min}$, respectively).

Table 1 Probit analysis of mortality of adult $B$. invadens to insecticides

\begin{tabular}{llllll}
\hline Insecticides & No. exposed & Slope $\pm \mathrm{SE}$ & $\mathrm{LC} C_{50}(\mathrm{FL}) \mathrm{ml} / \mathrm{L}^{-1}$ & $\mathrm{LC}_{90}(\mathrm{FL}) \mathrm{ml} / \mathrm{L}^{-1}$ & $X^{2}$ \\
\hline Cypermethrin+dimethoate & 30 & $3.18 \pm 1.15$ & $1.20(0.4-1.68)$ & $3.04(2.11-15.56)$ & 2.29 \\
Chlorpyrifos (Pyrinex) & 30 & $12.67 \pm 0.93$ & $0.81(0.55-0.89)$ & $1.03(0.93-1.58)$ & 1.04 \\
Diazinon (Diazol) & 30 & $3.92 \pm 2.33$ & $0.59\left(^{*}\right)$ & $3.10(2.53-4.09)$ & 5.25()$\left.^{*}\right)$ \\
Deltamethrin (Deltapaz) & 30 & $5.66 \pm 1.98$ & 0.54 & 0.41 \\
\hline
\end{tabular}

Legend: FL fiducial limits

${ }^{*}$ Fuducial limit could not be established 
Table 2 Mean lethal time (LT) for different concentrations of cypermethrin+dimethoate (Cydim super) and age of residues

\begin{tabular}{|c|c|c|c|}
\hline \multirow[b]{2}{*}{ Age of residue } & \multirow[b]{2}{*}{ Concentration $\left(\mathrm{ml} \mathrm{L}^{-1}\right)$} & \multicolumn{2}{|c|}{ Mean \pm S. E. lethal time (min) } \\
\hline & & $\mathrm{LT}_{50}$ & $\mathrm{LT}_{90}$ \\
\hline \multirow[t]{5}{*}{ FTP } & 0.0 & $>2880.00 \pm 0.00$ & $>2880.00 \pm 0.00$ \\
\hline & 1.6 & $66.33 \pm 8.78$ & $128.00 \pm 20 . .81$ \\
\hline & 2.3 & $62.00 \pm 15.52$ & $103.00 \pm 14.18$ \\
\hline & 3.00 & $29.67 \pm 13.68$ & $73.67 \pm 41.67$ \\
\hline & $\begin{array}{l}\text { LSD }(P<0.05) \\
\text { f-value } \\
p\end{array}$ & $\begin{array}{l}50.22 \\
10238.18 \\
<.001\end{array}$ & $\begin{array}{l}56.24 \\
3257.96 \\
<.001\end{array}$ \\
\hline \multirow[t]{5}{*}{ 3-DOTP } & 0.0 & $>2880.00 \pm 0.00$ & $>2880.00 \pm 0.00$ \\
\hline & 1.6 & $127.00 \pm 54.20$ & $194.00 \pm 72.00$ \\
\hline & 2.3 & $66.00 \pm 17.40$ & $105.33 \pm 27.51$ \\
\hline & 3.0 & $44.67 \pm 14.66$ & $60.33 \pm 18.46$ \\
\hline & $\begin{array}{l}\text { LSD }(P<0.05) \\
f \text {-value } \\
p\end{array}$ & $\begin{array}{l}96.00 \\
2270.89 \\
<.001\end{array}$ & $\begin{array}{l}129.19 \\
1217.66 \\
<.001\end{array}$ \\
\hline \multirow[t]{5}{*}{ 6-DOTP } & 0.0 & $>2880.00 \pm 0.00$ & $>2880.00 \pm 0.00$ \\
\hline & 1.6 & $144.33 \pm 55.47$ & $199.67 \pm 129.66$ \\
\hline & 2.3 & $74.33 \pm 17.32$ & $94.33 \pm 21.30$ \\
\hline & 3.0 & $42.67 \pm 9.74$ & $62.00 \pm 17.62$ \\
\hline & $\begin{array}{l}\operatorname{LSD}(P<0.05) \\
f \text {-value } \\
p\end{array}$ & $\begin{array}{l}96.10 \\
2248.90 \\
<.001\end{array}$ & $\begin{array}{l}114.30 \\
1555.47 \\
<.001\end{array}$ \\
\hline
\end{tabular}

Legend: FTP freshly treated panels, 3-DOTP 3-day-old-treated panels, 6-DOTP 6-day-old-treated panels

In the 3-day-old treated panels experiment, the highest concentration $\left(3.0 \mathrm{ml} \mathrm{L}^{-1}\right)$ was more toxic to the flies $\left(\mathrm{LT}_{50}=44.67 \pm 14.66 \mathrm{~min} ; \mathrm{LT}_{90}=60.33 \pm 18.46 \mathrm{~min}\right)$, but was only highly significantly $(P<0.001)$ more toxic than the least concentration level $\left(1.6 \mathrm{ml} \mathrm{L}^{-1}\right)\left(\mathrm{LT}_{50}=\right.$ $\left.127 \pm 54.20 \mathrm{~min} ; \mathrm{LT}_{90}=194 \pm 72.00 \mathrm{~min}\right)$. All concentration levels were significantly more toxic $(P<0.001)$ than the control $\left(\mathrm{LT}_{90}>2880.0 \mathrm{~min}\right)$.

Mean toxicity difference among concentration levels in the 6-day-old treated panels was the same as the 3day-old treated panels. Difference between the LT of the flies on the panels treated with 2.3 and $3.0 \mathrm{ml} \mathrm{L}^{-1}$ were not significant. Both concentration levels were, however, significantly more toxic $(P<0.001)$ to the adult $B$. invadens than the controls panels.

\section{Chlorpyrifos (Pyrinex $48 \mathrm{EC}$ )}

Table 3 summarizes the within treatment comparisons for the different doses of chlorpyrifos (Pyrinex) over the residues ages. The result for the freshly treated panel experiment indicated that all concentrations were highly significantly $(P<0.001)$ more toxic to the adult $B$. invadens than the controls. The median concentration (1.0 $\left.\mathrm{ml} \mathrm{L}{ }^{-1}\right)$ was more toxic $\left(\mathrm{LT}_{50}=39.33 \pm 9.39\right.$ and $\mathrm{LT}_{90}=$ $56.67 \pm 2.40 \mathrm{~min}$ ) than the least concentration, but these mean mortality times were not significantly different from the highest $\left(1.1 \mathrm{ml} \mathrm{L}^{-1}\right)$ and the lowest concentration $\left(0.9 \mathrm{ml} \mathrm{L}^{-1}\right)$.

On the 3-day-old treated panel experiments, there was a highly significant difference $(P<0.001)$ among mean lethal times for all treatment levels. The adult flies were more susceptible to the highest concentration $(1.1 \mathrm{ml}$ $\left.\mathrm{L}^{-1}\right)$ and gave the least lethal times $\left(\mathrm{LT}_{50}=19.33 \pm 5.28\right.$; $\mathrm{LT}_{90}=31.00 \pm 3.00 \mathrm{~min}$ ), acting faster than the same concentration on the freshly treated panels $\left(\mathrm{LT}_{50}=\right.$ $29.67 \pm 7.13$ and $\left.\mathrm{LT}_{90}=43.66 \pm 6.64 \mathrm{~min}\right)$. Similarly, the results obtained with the 6-day-old treated panels showed a similar pattern of toxicity to those for the 3day-old panels treated with chlorpyrifos (Pyrinex).

\section{Diazinon (Diazol $50 \mathrm{EW})$}

The result for experiments with panels freshly treated with varying concentrations of diazinon (Diazol) is shown in Table 4. It indicated that the highest concentration $(3.2 \mathrm{ml}$ $\mathrm{L}^{-1}$ ) was more toxic to the adult $B$. invadens and gave the lowest mean $\mathrm{LT}$ values $\left(\mathrm{LT}_{50}=25.33 \pm 4.41\right.$ and $\mathrm{LT}_{90}=$ $30.67 \pm 6.38 \mathrm{~min})$. Mean lethal time comparisons across the dosage concentrations were, however, not significantly different from each other, but were highly significantly different $(P<0.001)$ from the control.

Experiments with 3-day-old treated panels showed that all concentration levels significantly acted faster 
Table 3 Mean lethal time (LT) for different concentrations of chlorpyrifos (Pyrinex) and age of Residues

\begin{tabular}{|c|c|c|c|}
\hline \multirow[b]{2}{*}{ Age of residue } & \multirow[b]{2}{*}{ Concentration $\left(\mathrm{ml} \mathrm{L}^{-1}\right)$} & \multicolumn{2}{|c|}{ Mean \pm S. E. lethal time (min) } \\
\hline & & $\mathrm{LT}_{50}$ & $\mathrm{LT}_{90}$ \\
\hline & 0.9 & $66.33 \pm 16.50$ & $74.67 \pm 9.60$ \\
\hline & 1.0 & $39.33 \pm 9.39$ & $56.67 \pm 2.40$ \\
\hline & 1.1 & $29.67 \pm 7.13$ & $43.66 \pm 6.64$ \\
\hline & $\begin{array}{l}\operatorname{LSD}(P<0.05) \\
f \text {-value } \\
\mathrm{p}\end{array}$ & $\begin{array}{l}33.06 \\
19569.51 \\
<.001\end{array}$ & $\begin{array}{l}19.43 \\
56073.58 \\
<.001\end{array}$ \\
\hline \multirow[t]{5}{*}{ 3- DOTP } & 0.0 & $>2880.00 \pm 0.00$ & $>2880.00 \pm 0.00$ \\
\hline & 0.9 & $38.00 \pm 4.58$ & $53.00 \pm 9.00$ \\
\hline & 1.0 & $33.33 \pm 4.41$ & $31.00 \pm 3.00$ \\
\hline & 1.1 & $19.33 \pm 5.28$ & $31.00 \pm 3.00$ \\
\hline & $\begin{array}{l}\text { LSD }(P<0.05) \\
f \text {-value } \\
p\end{array}$ & $\begin{array}{l}13.44 \\
119600.00 \\
<.001\end{array}$ & $\begin{array}{l}17.06 \\
73617.82 \\
<.001\end{array}$ \\
\hline \multirow[t]{5}{*}{ 6-DOTP } & 0.0 & $>2880.00 \pm 0.00$ & $>2880.00 \pm 0.00$ \\
\hline & 0.9 & $34.33 \pm 2.33$ & $48.33 \pm 4.10$ \\
\hline & 1.0 & $37.33 \pm 1.20$ & $50.00 \pm 6.11$ \\
\hline & 1.1 & $26.33 \pm 1.46$ & $35.33 \pm 1.33$ \\
\hline & $\begin{array}{l}\operatorname{LSD}(P<0.05) \\
f \text {-value } \\
p\end{array}$ & $\begin{array}{l}5.00 \\
900800.00 \\
<.001\end{array}$ & $\begin{array}{l}12.19 \\
143800.00 \\
<.001\end{array}$ \\
\hline
\end{tabular}

Legend: FTP freshly treated panels, 3-DOTP 3-day-old-treated panels, 6-DOTP 6-day-old-treated panels

Table 4 Mean lethal time (LT) for different concentrations of diazinon (Diazol) and age of residues

\begin{tabular}{|c|c|c|c|}
\hline \multirow[b]{2}{*}{ Age of residue } & \multirow[b]{2}{*}{ Concentration $\left(\mathrm{ml} \mathrm{L}^{-1}\right)$} & \multicolumn{2}{|c|}{ Mean \pm S. E. lethal time (min) } \\
\hline & & $\mathrm{LT}_{50}$ & $\mathrm{LT}_{90}$ \\
\hline \multirow[t]{6}{*}{$\overline{\text { FTP }}$} & 0.0 & $>2880.00 \pm 0.00$ & $>2880.00 \pm 0.00$ \\
\hline & 1.8 & $33.70 \pm 16.5$ & $48.88 \pm 7.00$ \\
\hline & 2.5 & $34.67 \pm 3.76$ & $39.00 \pm 7.00$ \\
\hline & 3.2 & $25.33 \pm 4.41$ & $30.67 \pm 6.38$ \\
\hline & $\operatorname{LSD}(P<0.05)$ & 12.38 & 19.21 \\
\hline & $\begin{array}{l}f \text {-value } \\
p\end{array}$ & $\begin{array}{l}140700.00 \\
<.001\end{array}$ & $\begin{array}{l}58152.10 \\
<.001\end{array}$ \\
\hline \multirow[t]{5}{*}{ 3-DOTP } & 0.0 & $>2880.00 \pm 0.00$ & $>2880.00 \pm 0.00$ \\
\hline & 1.8 & $27.67 \pm 3.38$ & $40.00 \pm 5.00$ \\
\hline & 2.5 & $24.00 \pm 3.06$ & $38.33 \pm 5.36$ \\
\hline & 3.2 & $13.67 \pm 2.73$ & $28.67 \pm 4.70$ \\
\hline & $\begin{array}{l}\operatorname{LSD}(P<0.05) \\
f \text {-value } \\
p\end{array}$ & $\begin{array}{l}8.66 \\
289500.00 \\
<.001\end{array}$ & $\begin{array}{l}14.20 \\
106600.00 \\
<.001\end{array}$ \\
\hline \multirow[t]{5}{*}{ 6-DOTP } & 0.0 & $>2880.00 \pm 0.00$ & $>2880.00 \pm 0.00$ \\
\hline & 1.8 & $24.67 \pm 3.38$ & $30.66 \pm 3.40$ \\
\hline & 2.5 & $19.00 \pm 1.16$ & $26.33 \pm 6.11$ \\
\hline & 3.2 & $14.67 \pm 2.33$ & $20.66 \pm 1.86$ \\
\hline & $\begin{array}{l}\operatorname{LSD}(P<0.05) \\
f \text {-value } \\
p\end{array}$ & $\begin{array}{l}7.00 \\
449100.00 \\
<.001\end{array}$ & $\begin{array}{l}8.37 \\
309300.00 \\
<.001\end{array}$ \\
\hline
\end{tabular}


than the control. The highest concentration level $(3.2 \mathrm{ml}$ $\left.\mathrm{L}^{-1}\right)$ was highly significantly $(P<0.001)$ more toxic to the flies than the least concentration $\left(1.8 \mathrm{ml} \mathrm{L}^{-1}\right)\left(\mathrm{LT}_{50} \mathrm{~S}\right.$ $=13.67$ and $33.7 ; \mathrm{LT}_{90} \mathrm{~S}=28.67$ and $40 \mathrm{~min}$, respectively).

On 6-day-old treated panels experiment with diazinon (Diazol), only the mean mortality times of the least concentration $\left(1.8 \mathrm{ml} \mathrm{L}^{-1}\right)$ and the highest concentration $\left(3.2 \mathrm{ml} \mathrm{L}^{-1}\right)$ were highly significantly different $(P<$ $0.001)$. Generally, there was an overall surprising decrease in mortality times with increase in the age of residues on panels treated with diazinon (Diazol) over the experimental period (Table 4).

\section{Deltamethrin (Deltapaz)}

The results for the mean lethal times (LT) for different concentrations of deltamethrin (Deltapaz) across the ages of residues are presented in Table 5. In the freshly treated panels experiments, the highest concentration was highly significantly $(P<0.001)$ more toxic than all the treatment levels and the control. There were, however, no significant differences between the least concentration and the median concentration $\left(2.6 \mathrm{ml} \mathrm{L}^{-1}\right.$ and $3.4 \mathrm{ml} \mathrm{L}^{-1}$, respectively).

On the 3-day-old panel experiments, control panels significantly $(P<0.001)$ exhibited no toxicity (LT > $2880.00 \mathrm{~min}$ ) to the adult $B$. invadens relative to all the three concentration levels of deltamethrin (Deltapaz). $\mathrm{LT}_{50}$ of the highest concentration $(411.67 \pm 243.68 \mathrm{~min})$ was highly significantly $(P<0.001)$ lower than that of the least concentration $(1291.00 \pm 38.67 \mathrm{~min})$. The $\mathrm{LT}_{90}$, however, indicated that median concentration level was also highly significantly different $(P<0.001)$ from the least doses, but not from the highest concentration. The pattern of toxicity of 6-day-old treated panels was similar to that of the freshly treated panels. Deltamethrin (Deltapaz), however, showed a progressive decrease in toxicity with increase in the age of residues.

\section{Discussion}

The pestilence of B. invadens on host fruits depends on the mobility of the adult flies and most especially the females that lay the eggs (Vayserres et al. 2008). Laboratory studies provide avenue to estimate the toxicities of insecticides on adult flies by excluding the effects of the environmental factors/variables and their variation and can also raise reproducible quantitative data (Mahmoudvand et al., 2011; Raga \& Sato, 2006). Similarly, tephritid fruit flies control relies on adult suppression ((Ekesi \& Billah, 2006). Similarly, the LC data can be used to rate the acute insecticides toxicities (Mahmoudvand et al., 2011), from highly toxic $\mathrm{LC}_{50}$ 0.001-1.99, moderately toxic 2.0-10.99, and non-toxic $>11.0 \mathrm{ml} \mathrm{L}^{-1}$ (Sunil, Thippaiah, Jagadish, \& Chakravarthy, 2016). Lethal

Table 5 Mean lethal time (LT) for different concentrations of deltamethrin (Deltapaz)

\begin{tabular}{|c|c|c|c|}
\hline \multirow[b]{2}{*}{ Age of residues } & \multirow[b]{2}{*}{ Concentration $\left(\mathrm{ml} \mathrm{L}^{-1}\right)$} & \multicolumn{2}{|c|}{ Mean \pm S. E. lethal time (min) } \\
\hline & & $\mathrm{LT}_{50}$ & $\mathrm{LT}_{90}$ \\
\hline \multirow[t]{5}{*}{ FTP } & 0.0 & $>2880.00 \pm 0.00$ & $>2880.00 \pm 0.00$ \\
\hline & 2.6 & $360.30 \pm 24.91$ & $547.33 \pm 32.27$ \\
\hline & 3.4 & $318.33 \pm 61.76$ & $462.00 \pm 14.76$ \\
\hline & 4.0 & $153.00 \pm 14.53$ & $431.33 \pm 14.76$ \\
\hline & $\begin{array}{l}\operatorname{LSD}(P<0.05) \\
f \text {-value } \\
p\end{array}$ & $\begin{array}{l}111.20 \\
1464.50 \\
<.001\end{array}$ & $\begin{array}{l}64.84 \\
3648.17 \\
<.001\end{array}$ \\
\hline \multirow[t]{5}{*}{3 -DOTP } & 0.0 & $>2880.00 \pm 0.00$ & $>2880.00 \pm 0.00$ \\
\hline & 2.6 & $1291.00 \pm 29.20$ & $1691.00 \pm 51.00$ \\
\hline & 3.4 & $669.67 \pm 136.01$ & $844.67 \pm 93.18$ \\
\hline & 4.0 & $411.67 \pm 243.68$ & $771.67 \pm 93.18$ \\
\hline & $\begin{array}{l}\text { LSD }(P<0.05) \\
f \text {-value } \\
p\end{array}$ & $\begin{array}{l}457.50 \\
62.36 \\
<.001\end{array}$ & $\begin{array}{l}233.90 \\
187.39 \\
<.001\end{array}$ \\
\hline \multirow[t]{5}{*}{ 6- DOTP } & 0.0 & $>2880.00 \pm 0.00$ & $>2880.00 \pm 0.00$ \\
\hline & 2.6 & $1335.00 \pm 33.76$ & $1733.00 \pm 210.00$ \\
\hline & 3.4 & $1277.33 \pm 38.76$ & $1459.00 \pm 51.10$ \\
\hline & 4.0 & $790.00 \pm 147.31$ & $1110.33 \pm 205.00$ \\
\hline & $\begin{array}{l}\operatorname{LSD}(P<0.05) \\
f \text {-value } \\
p\end{array}$ & $\begin{array}{l}352.40 \\
135.06 \\
<.001\end{array}$ & $\begin{array}{l}485.50 \\
26.51 \\
<.001\end{array}$ \\
\hline
\end{tabular}

Legend: FTP freshly treated panels, 3-DOTP 3-day-old-treated panels, 6-DOTP 6-day-old-treated panels 
concentration (LC) values obtained in our study are, therefore, in the overall low, ranging from 0.59 to 3.10 $\mathrm{ml} \mathrm{L}^{-1}$. This implies that all the chemical insecticides tested are good candidate products for the containment of $B$. invadens adult population explosions.

This study also reveal that diazinon (Diazol) had the highest toxicity $\left(\mathrm{LC}_{50} 0.59 \mathrm{ml} \mathrm{L}^{-1}\right)>$ chlorpyrifos (Pyrinex) $\left(\mathrm{LC}_{50} 0.81 \mathrm{ml} \mathrm{L}^{-1}\right)>$ cypermethrin+dimethoate (Cydim super) $\left(\mathrm{LC}_{50} 1.20 \mathrm{ml} \mathrm{L}{ }^{-1}\right)>$ deltamethrin (Deltapaz) $\left(\mathrm{LC}_{50} 3.10 \mathrm{ml} \mathrm{L}{ }^{-1}\right)$. This implies that deltamethrin is the least effective against the adult $B$. invadens. However, our result appears to be in contrast with the findings of Mahmoudvand et al. (2011) and Mehta et al. (2000) who reported that deltamethrin is more effective against Dacus ciliates Loew compared to dimethoate, malathion, endosulfan, and chlorpyrifos, an active ingredients similar to that of cypermethrin+dimethoate (Cydim super) and chlorpyrifos (Pyrinex) used in our studies. Also, contrary to our findings, chlorpyrifos has been reported to be of inferior efficacy when compared with lamba-cyhalothrin a pyrethroids like deltamethrin in our study (Khursheed \& Raj, 2012). This disparity in result may be partly attributed to species differential response to insecticidal products or due to variable environmental conditions of the test scenarios or both factors combined (Bradbury \& Coats, 1989; Worthing, 1991). Ours was a laboratory trial while Khursheed and Raj (2012) results are from field trials. Also, in a bait study, Mahat and Drew (2015) reported that females of B. tyroni, a close relative of B. invadens (Ekesi \& Billah, 2006), were found to be more deterred from feeding of baits containing chlorpyrifos and malathion with a resultant rapid knockdown and higher mortalities. This is in tandem with our findings in this study that chlorpyrifos (chlorpyrifos (Pyrinex) is more effective than deltamethrin (Deltapaz) and cypermethrin+dimethoate (Cydim super). Conversely, an overlap was found between the 95\% FL of the tested products with exception to dizinon (FL could not be established) indicating that all the compounds exhibited significant toxicities to the adult $B$. invadens. Furthermore, the $B$. invadens adults were more sensitive to diazinon (Diazol) and most tolerant to deltamethrin (Deltapaz). This implies that diazinon (Diazol) is the most efficacious among the entire insecticidal products tested in this study for the suppression of adult population of $B$. invadens. Other trials on the control of fruit flies using similar products include Khan and Khattak (2000) which tested trichlorfon and malathion as both cover sprays and bait against melon fruit flies $\mathrm{Bac}$ trocera cucurbitacea on musk melon Cucumis melon with both products performing much better than the control plots. Similar studies with Trichlorfon, malathion, endosulfan, Dimetheote, and Curbicron reported impressive performance against $B$. curcubitae on $C$. melon (Agarwal, Sharma, \& Rehman, 1987; Chughtai \& Baloch, 1988; Chughtai, Khan, \& Islam, 1984; Hussain \& Khan, 1980).

The result of the dose-dependent residual response of the adult $B$. invadens to cypermethrin+dimethoate (Cydim super) concentrations exhibited a variable concentration-dependent residual lethal times $\left(\mathrm{LT}_{50}\right.$ and LT 90). The highest concentration has shown to exert least mortality times which were only significantly $(P<$ $0.001)$ lower at $\mathrm{LT}_{90}$ for the freshly treated panel experiment. This implies that even concentrations lower than the field recommended rate for this insecticide can still give a good control of adult $B$. invadens. Residual toxicities on 3- and 6-day-old treated panels showed low lethal times for the adult $B$. invadens $\left(\mathrm{LT}_{50} 42.67 \pm 7.4-\right.$ 144; LT 90 62-199.67 min on 6-day-old treated panels).

Cypermethrin acts as a stomach and contact insecticide. Its structure is based on pyrethrum, a natural insecticide found in chrysanthemum flowers, but it has a higher biological activity and is more stable than its natural model (Anonymous, 1995; Leahey, 1985). The relatively rapid degradation of cypermethrin means that it is not generally found as a residue in food (Anonymous, 1995). Cypermethrin is therefore classified by the World Health Organization (WHO) as "moderately hazardous" (Class II) (FAO/ WHO, 1996). Dimethoate on the other hand is a widely used organophosphorus (OP) insecticide applied to kill mites and insects systemically and on contact (EXTOXNET, 1996). Like all OPs, dimethoate acts by interfering with the activities of cholinesterase, an enzyme essential for the proper functioning of the nervous system of insects and humans (EXTOXNET, 1996). The foregoing coupled with our findings can add up to guarantee the safe use of cypermethrin+dimethoate (Cydim super) for B. invadens control.

chlorpyrifos (Pyrinex) (chlorpyrifos $480 \mathrm{~g} / \mathrm{L}$ ) showed the same trend of result as the freshly treated panels across the concentrations tested. Residual toxicities were found to be more acute on the 3- and 6-day-old treated panels relative to freshly treated panels. Chlorpyrifos (Pyrinex) contains chlorpyrifos $480 \mathrm{~g} / \mathrm{L}$. Chlorpyrifos is a broad-spectrum organophosphate insecticide that inhibits acetyl cholinesterase in insect nervous system. Chlorpyrifos acts on pests primarily as a contact poison, with some action as a stomach poison (EXTOXNET, 1993, 1996). Our study equally demonstrates that it can be used successfully for the control of fruit flies with particular emphasis on adult $B$. invadens.

Trends of lethal times among concentrations across the ages of treated panels similar to those of cypermethrin+dimethoate (Cydim super) and chlorpyrifos (Pyrinex) were found for both diazinon (Diazol) and deltamethrin (Deltapaz). Diazinon (Diazol) is a broadspectrum insecticide that contains diazinon and is an 
organophosphate and a non-systemic insecticide, effective against a wide range of insect pest on all major agricultural crops. Our study points to its greater propensity of serving as a dependable insecticide against adult $B$. invadens. Deltamethrin on the one hand is a synthetic insecticide based structurally on natural pyrethrums, which rapidly paralyze the insect nervous system giving a quick knockdown effect (Haug \& Hoffman, 1990; Hayes \& Laws, 1990). Death of insects exposed to deltamethrin seems to be due to irreversible damage to the nervous system occurring when poisoning lasts more than a few hours (Leahey, 1985). Its poisoning occurs through cuticular penetration or oral uptake (EXTOXNET, 1995: Hayes \& Laws, 1990), with high compatibilities with other common insecticides and fungicides (Thompson 1998). Deltamethrin is also reported to have a very good residual activity for outdoor uses (field crops, cattle dip, and tsetse) as well as indoor uses (mosquitoes, stable flies, horseflies, fleas, cockroaches, stored product insects) (Bradbury \& Coats, 1989; Worthing, 1991). It is considered the most powerful of the synthetic pyrethroids. It is up to three orders more active than some pyrethroids (Bradbury \& Coats, 1989; Spencer 1981). However, it has shown a lesser residual toxicities in this our study, even when compared to its sister synthetic pyrethroids, cypermethrin on the acute toxicity ratings.

Lastly, this study revealed a general trend of the lowest doses becoming less effective in causing significantly slower mortalities along the ages of the panels. There is, therefore, a general decline of the efficiency of the least doses levels for all the tested products with an increasing age of the residues. Decline in toxicities of insecticides in the field as well as under laboratory conditions against fruit flies with an increasing treatment time has been reported (Mahat \& Drew, 2015; Peck \& Mcquate, 2000; Reynolds, Osborne, \& Barchia, 2017; William, Valle, \& Vanuela, 2003)

\section{Conclusion}

In conclusion, the results of this study suggest that all the tested insecticidal products can be a potential tool for the control of B. invadens in Ghana and similar ecologies. Diazinon is, however, the most effect product owing to the least LC and LT times. However, actual field trials are required to validate our result under the prevailing agro-climatic conditions.

\section{Abbreviations}

LC: Lethal concentrationLTLethal timeECEmulsifiable

concentratesARPPISAfrican Regional Postgraduate Programme in Insect ScienceFLFiducial limitsLSDLeast significant

differenceLtdLimitedANOVAAnalysis of varianceet al.And othersFTPFreshly treated Panels3-DOTP3-Day-old treated panels6-DOTP6-Day-old treated panels

\section{Acknowledgements}

We gratefully acknowledge the German Academic Exchange Service (DAAD) for funding this research as part of the first authors work for his M. Phil in Entomology at African Regional Postgraduate Programme in Insect Science (ARPPIS)-West African sub-regional center, University of Ghana, Legon, Ghana. All facilities provided by ARPPIS and University of Ghana are hereby acknowledged.

\section{Authors' contributions}

AG had conceived the idea, performed the practical section, and collected the samples, analyzed the data, and wrote his master thesis (at which this manuscript is based on). MKB had identified the insect and carried out the taxonomic part of this study. DO, KA, and MKB helped in designing the study, supervised the preparation of the experiment, and helped in writing the manuscript. All authors read and approved the final manuscript.

\section{Funding}

Funding for the entire Master degree program for the first author was provided by German DAAD.

Availability of data and materials

Data is available on request.

Ethics approval and consent to participate

Not applicable for this kind of research.

Consent for publication

Not applicable.

\section{Competing interests}

The authors declare that they have no competing interests.

\section{Author details}

${ }^{1}$ Department of Crop Protection, Modibbo Adama University of Technology, Yola, Nigeria. ${ }^{2}$ Department of Crop Science, University of Ghana, Legon,

Ghana. ${ }^{3}$ Agricultural Research Centre, Kade, Institute of Agricultural Research, University of Ghana, Legon, Ghana. ${ }^{4}$ Department of Animal Biology and Conservation Sciences, University of Ghana, Legon, Ghana.

Received: 4 October 2019 Accepted: 11 February 2020

Published online: 04 May 2020

\section{References}

Abbott, W. S. (1925). A method of computing the effectiveness of an insecticides. Journal of Economic Entomology, 18(2), 265-226.

Agarwal, W. L., Sharma, D. P., \& Rehman, O. (1987). Melon fruit fly and its control. Indian Horticulture, 32(3), 10-11.

Anonymous (1995). Cypermethrin- asynthethic pyrethroid. Pesticides News, 30, $20-21$.

Badii, K. B., Billah, M. K., Afreh-Nuamah, K., \& Obeng-Ofori, D. (2012). Farmers' knowledge and perceptions of fruit fly pests and their management in Northern Ghana. Greener Journal of Agricultural Sciences, 2(8), 412-423.

Badii, K. B., Billah, M. K., Afreh-Nuamah, K., \& Obeng-Ofori, D. (2015). Species composition and host range of fruit-infesting flies (Diptera: Tephritidae) In Northern Ghana. International Journal of Tropical Insect Science, 35(3), 137151

Bateman, M. A. (1982). Chemical methods for suppression or eradication of fruit fly populations. In R. A. I. Drew, G. H. S. Hooper, \& M. A. Bateman (Eds.) Economic Fruit Flies of the South Pacific Region, (2nd ed., pp. 115-128). Brisbane: Queensland Department Of Primary Industries.

Billah, M. K., \& Mansell, M. W. (2006). Fruit Fly Taxonomy, Pp. H 1- 19. In S. Ekesi, \& M. K. Billah (Eds.), A field guide to the management of economically important Tephritid fruit fly in Africa, (p. 206). Nairobi: ICIPE Science Press.

Bradbury, S. P., \& Coats, J. R. (1989). Toxicokinetics and toxicodynamics of pyrethroid insecticides in fish. Environmental Toxicological Chemistry, 8, 373380

Cheng, C. L., Cho, I. K., \& Li, Q. X. (2009). Insecticidal activity of basil oil, TransAnethole, Estragole, and linalool to adult fruit flies of Ceratitis Capitata, Bactrocera Dorsalis, And Bactrocera Cucurbitae. Journal of Economic Entomology, 102(1), 203-209. 
Chughtai, G. H., \& Baloch, U. K. (1988). Efficacy of various insecticides against the larvae of Dacus Cucurbitae Coq. Pakistan Journal of Agricultural Resources, 9 192-194.

Chughtai, G. H., Khan, S. D., \& Islam, Q. U. (1984). Chemical control of melon fruit fly. Pakistan Journal of Agricultural Resources, 5, 140-142.

Copeland, R. S. (2006). Host fruit processing- purpose, tools and methodology, F1 - 11. In S. Ekesi, \& M. K. Billah (Eds.), A Field Guide To The Management Of Economically Important Tephritid Fruit Flies In Africa, (p. 206). Nairobi: ICIPE Science Press.

De Meyer, M. (1998). Revision of the subgenus Ceratitis (Ceratalaspis) Hancook (Diptere: Tephritidae). Bulletin of Entomological Research, 88, 439-467.

De Meyer, M. (2000). Systematic revision of the subgenus Ceratitis Macleay (Diptera: Tephritidae). Journal of the Linneaus Society of London, 128, 439-467.

Drew, R. A. I., Tsuruta, K., \& White, I. M. (2005). A new species of pest fruit fly (Diptera: Tephritidae: Dacinae) From Sri Lanka and Africa. African Entomology: Journal of the Entomological Society of Southern Africa, 13, 149-154.

Ekesi, S., \& Billah, M. K. (2006). A field guide to the management of economically important tephritid fruit flies in Africa, (p. 206). Nairobi: ICIPE Science Press.

Ekesi, S., Nderitu, P. W., \& Rwomushana, I. (2006). Field infestation and demographic parameters of the fruit fly Bactrocera Invadens (Diptera: Tephritidae) in Africa. Bulletin of Entomological Research, 96, 379-386.

EPA, 2008. List of recommended insecticides for horticultural crops in Ghana. Http://Www.Epaghana.Gov. Accessed on 10/09/2009

EXTOXNET (1993). Pesticide Management Information Programme 'Dimethoate' Extoxnet Pesticide Information Notebook. New York: Cornell University Http:// Www.Extoxnet.Orst.Edu/Pips/Dimethoa.Htm. Accessed on 10/09/2012.

EXTOXNET. 1995. Pesticides information profile- deltamethrin. Http://Www. Extoxnet.Orst.Edu/Pips/Deltamet.Htm. Accessed on 10/09/2009

EXTOXNET. 1996. Pesticides information profile-dimethoate. Http://Www. Extoxnet.Orst.Edu/Pips/Dimethoa.Htm. Accessed on 10/09/2008.

FAO/ WHO (1996). Who/ Fao data sheets on pesticides. \# 90. Rome: Fao.

Genstat (2007). Genstat Statistical Packages (Genstat Release 9.2 (PCWindows)), (9th ed., ). Harpenden: Lawes Agricultural Trust, Rothamsted Experimental Station.

Haug, G., \& Hoffman, H. (Eds.) (1990). Chemistry of plant protection 4: synthetic pyrethroid insecticides: structures and properties, (p. 437). Berlin, Heidelberg, New York: Springer-Verlag.

Hayes, W. J., \& Laws, E. R. (Eds.) (1990). Handbook of pesticide toxicology, general principles, (vol. 1). New York: Academic Http://Www.Who.Int/lpcs/ Publications/Training/Poison/Guidelines/Poison/Control/En/Index8.Html-43k Accessed 20 June 2009

Hussain, G., \& Khan, S. (1980). Chemical control of fruit in Dera Ismail Khan. Frontier Journal of Agricultural Resources, 4, 80-82

Khan, S. M., \& Khattak, S. (2000). Chemical control of melon fruit fly (Bactrocera Curcubitae) (Coq) on muskmelon (Cucumis Melo) by malathion and dipterex in D. I. Khan. Pakistan Journal of Biological Sciences, 3(8), 1299-1300.

Khursheed, S., \& Raj, D. (2012). Bioefficacy of certain insecticides and biopesticides against melon fruit flies Bactrocera Spp. Pest Management in Horticultural Ecosystems, 18(2), 143-148

Leahey, J. P. (1985). The pyrethroid insecticides. Journal of Economic Entomology, 94(1), 253-263.

Mahat, K., \& Drew, R. A. I. (2015). Evaluation of protein bait laced with various insecticides on the Queensland fruit fly (Diptera: Tephritidae): attraction, feeding, mortality and bait persistence. In B. Sabater-Munoz et al. (Eds.), Xil International Citrus Congress-International Society of Citriculture, (pp. 18-23).

Mahmoudvand, M. Garian, A. S., Rahmi, H., Nezhad, A. R. A., Mahajeri, M. E, Ali, M. , \& Fazel, M. M. (2011). Susceptibility of males and females of cucumber fruit fly Dacus Ciliates to various insecticides in the laboratory conditions. Jordan Journal of Biological Sciences, 4(4), 213-218.

Mehta, P.K., Chandel, R.S., andKashyap, N.P. (2000). Control of fruit fly, Bactrocera cucurbitae (Coq.) on cucumber in Himachal Predash. Pestology, 24 (10): $53-$ 55.

Moore, D. J. and Miller, D. M., (2006). Laboratory evaluation of insecticide product efficacy for the control of Cimex lectularius. Journal of Economic Entomology 99 (6): 2080-2086.

Peck, S. L., \& Mcquate, G. T. (2000). Fields tests of environmentally friendly malathion replacement to suppress wild Mediterranean fruit fly (Diptera: Tephritidae) populations. Journal of Economic Entomology, 93, 280-289.

Raga, A., \& Sato, M. E. (2006). Time-mortality for fruit flies (Diptera: Tephritidae) exposed to insecticides in laboratory. Neotropical Entomology, 73(1), 73-77.

Reynolds, O. L., Osborne, T. J., \& Barchia, I. (2017). Efficacy of chemical for the potentials management of the Queensland fruit fly Bactrocera Tyroni
(Froggat) (Diptera: Tephritidae). Insects, 8, 49. https://doi.org/10.3390/ insects8020049.

Rwomushana, I., Ekesi, S., Gordon, I., \& Ogal, C. K. P. (2008). Host plants and host plant preference studies for Bactrocera Invadens (Diptera: Tephritidae) in Kenya, a new invasive fruit fly species in Africa. Annals of the Entomological Society of America, 101(2), 331-340.

Spencer, E. Y., (1981). Guide to the Chemicals Use in Crop Protection. 7th edition. Publication 1093. Research Branch. Agriculture Canada. http://www.pic.int/ INCs/CRC2/112add1)/English/CRC\%20212\%20add\%201\%20cyhexatin\%2 Ocanada\%20rev. Accessed 20 Aug 2017.

Sunil, M., Thippaiah, K., Jagadish, S., \& Chakravarthy, A. K. (2016). Efficacy of insecticides against melon fruit fly Bactrocera Cucurbitae (Coquillett) in bitter gourd. Entomon, 41(3), 233-238.

Thompson, W. T. (1998). Agricultural Chemicals. Book I - Insecticides, (p 270). Fresno: Thomson Publications.

Umeh, V. C., Garcia, L. E., \& De Meyer, M. (2008). Fruit flies of citrus in Nigeria: species diversity, relative abundance and spread in major producing areas. Fruits, 63, 145-153. https://doi.org/10.1051/Fruits:2008004.

Urbaneja, A., Chueca, P. Monto' n, H., Pascual-ruiz, S., Dembilio, O., Vanaclocha, P. Abad, Moyano, R., Pina, T., and Castan Era. (2009). Chemical alternatives to Malathion for controlling Ceratitis capitata (Diptera: Tephritidae), and their side effects on natural enemies in Spanish citrus orchards. Journal of Economic Entomology 102 (1): 203-209.

Vayssières, J.-F., Sanogo, F., \& Noussourou, M. (2007). Inventory of the fruit fly species (Diptera: Tephritidae) linked to the mango tree in Mali and tests of integrated control. Fruits, 62, 329-341.

Vayssie'res, J.-F., S. Korie, O. Coulibaly, L. Temple, and S. Boueyi. (2008). The mango tree in central and northern Benin: Cultivar inventory, yield assessment, infested stages and loss due to fruit flies (Diptera: Tephritidae). Fruits 63: 335-348.

Vayssières, J.-F., Vannière, H., Gueye, P. S., Barry, O., Hanne, A. M., Korie, S., .. Delhove, G. (2011). Preliminary inventory of fruit fly species (Diptera: Tephritidae) in mango orchards in the Niayes Region, Senegal, In 2004. Fruits, $66,91-108$.

White, I. M., \& Elson-Harris, M. M. (1992). Fruit flies of economic significance: their identification and bionomics, (p. 601). Wallingford: Cab International.

Wih, K. \& Billah, M. K. (2012). Diversity of fruit flies and Mealybugs in the Upper West Region of Ghana. Journal of Developments in Sustainable Agriculture, 7, 39-45.

William, T., Valle, J., \& Vanuela, E. (2003). Is the naturally derived spinosad insescticides compartible with insect natural enemies. Bicontrol Science And Technology, 13, 459-475.

Worthing, C. E. (Ed.) (1991). The Pesticide Manual: A World Compendium, (9th ed., ) Published By The British Crop Protection Council. Http:/Mww.Ermanz.Govt.Nz/ Chemicals/Chemicaldisplay.Aspx?Substanceid=2131-32k. Acessed 03/10/2009.

\section{Publisher's Note}

Springer Nature remains neutral with regard to jurisdictional claims in published maps and institutional affiliations.

\section{Submit your manuscript to a SpringerOpen ${ }^{\circ}$ journal and benefit from:}

- Convenient online submission

- Rigorous peer review

- Open access: articles freely available online

- High visibility within the field

- Retaining the copyright to your article

Submit your next manuscript at $>$ springeropen.com 